UDC 340.132 .6

DOI https://doi.org/10.32837/apdp.v0i87.2806

Yu. I. Matat

\title{
THE ROLE OF INTERPRETATION OF LAW IN THE MECHANISM OF BRIDGING GAPS IN LAW
}

Formulation of the problem. In the legal systems of continental European law, the interpretation of law plays a very important and sometimes crucial role. This is due to the special role of the judge, which consists not only in his activities in relation to formal, pre-established regulations, but also in the application of the latter in the context of the legal system based on its fundamental values.

The state of scientific research. Problems of interpretation of law and its role in bridging gaps in the law were studied by such scientists as O.V. Averin, O.T. Bonner, O.N. Vereshchagin, M.S. Kelman, D.O. Tumanov, S.P. Pogrebniak, P.M. Rabinovych, Yu.M. Todyka, H.O. Khrystova, S.P. Cherednychenko, S.V. Shevchuk and others. However, some aspects of the above issues related to the relationship between gaps in the law and the interpretation of law, such as: (a) the study of specific types of gaps and the role of clarification of legal norms in the process of overcoming existing gaps; (b) disclosure of the essence of the disseminating interpretation of the law and its application by analogy; (c) determining the specifics of the interpretation of the rules applied by analogy, as well as the role of official interpretation in the process of bridging gaps, remain insufficiently studied, which, given the great practical importance of these issues, determines the relevance of their research.

The purpose of the article is to clarify the legal nature of the interpretation of law, its features, as well as the role in the process of bridging gaps in law, in particular, the study of the specifics of the interpretation of norms applied by analogy, in the case of gaps in law, as well as disclosing the meaning of interpretation activities for the implementation of completion paths (development) of law.

Statement of basic materials. Regulating the procedure for exercising the rights and fulfilling the responsibilities of the participants in legal relations, the rules of law are characterized by the high degree of formalism, which largely determined the specifics of the gaps that occur in them. The gap in law in the theory of law is understood as the absence of the appropriate regulatory and legal prescription, which is necessary for the regulation of specific social relations that are in the sphere of legal regulation $[1$, p. 378]. We are talking, in particular, not only about cases when there is no rule of law at all, but also about the situation where it (or part of it) is not clearly formulated, as a result of which we have the formal gap. According to O.T. Bonner, the formal gap is the situation associated with the absence of the law that would directly answer the question. However, this does not mean that there is no corresponding legal norm, and in this case, the law enforcement body has to create it to the certain extent, taking into account various methods of interpreting law [2, p. 39]. Agreeing with the opinion of the scientist, D.O. Tumanov defines this concept as the situation in which the law 
enforcement agency should not create a rule, but reconstruct its true logical meaning [3, p. 99]. This can be achieved only through the interpretation of the law, which, according to the apt statement of $\mathrm{O} . \mathrm{V}$. Averin, is "the most complex intellectual procedure that requires at least 2 conditions: the deep knowledge of not only the current law, but also quite complex rules of legal hermeneutics" [4, p. 172].

By its nature, the interpretation is aimed at clarifying the true meaning of the law. It should be borne in mind that the latter, due to the property of human speech, can admit the existence of several variants of its understanding. Therefore, the interpretation does not change or abolish the law, but only concretizes it, gives it the meaning that is embedded in it.

The need for interpretation is organically related to the use of techniques and means of legal techniques in the development of the legal act, which, in turn, are conditioned by several aspects of the external form of law, namely: (a) the form of external verbal and documentary presentation of the content of legal prescriptions and (b) normative, specifically legal expression of this content. Along with these objective grounds, the need for interpretation is also explained by the imperfection of the wording of the law of the will of the legislator. In view of this, the interpretation of legal acts helps to eliminate the shortcomings of their form. Incorrect or incomplete use of techniques and tools of legal technique, shortcomings in the style of legal acts can be eliminated by interpretation. This is what gives the grounds for S.S. Alekseev to consider interpretation as a kind of continuation of legal techniques, the purpose of which is to ensure the completeness and accuracy of the expression of the will enshrined in these acts, its full disclosure and proper effective implementation [5, p. 505]. So, it can be argued that through various methods of interpretation such kind of gaps as formal gaps are overcome.

In the process of exercising the right, it is important not only to interpret one or another formally established legal prescription, but also to explain it in general - its meaning, principles, socio-political content, and so on. Only the in-depth interpretation can serve as the appropriate basis for individual sub-normative regulation and concretization of norms, analogy of law, their subsidiary application in accordance with the requirements of legality. To achieve these objectives, law enforcement authorities use the expansive interpretation, the purpose of which is to reveal the true meaning of the legal norm, which is broader than its literal meaning. At the same time, it is extremely important that in the process of such interpretation the content laid down by the legislator remains unchanged [3, p. 106]. How rightly S.P. Pogrebniak remarks in this regard, the interpreter must choose the version of interpretation within the framework of the law, and not outside it [6, p. 126]. At the same time, the interpretation should be based on the general meaning of the norm, which determines its main purpose.

Expanded interpretation is carried out by the courts and as a result of the application of constitutional norms on human rights and fundamental freedoms, when their content is additionally determined by judicial lawmaking [7, p. 548]. For example, the European Court in the case of Yvonne van Duyn v. Home Office (Case 41/74 van Duyn v. Home Office) established the new legal provision as the result of clarifying the content of the principle of legal certainty, which, in his opinion, means that inter- 
ested parties should be able to rely on the obligations assumed by the state, even if they are in the legislative act that does not have automatic direct action at all. Such action of the specified principle is connected with another - with the principle of responsibility, which is that the state should not invoke its own violation of obligations in order to prevent responsibility. However, if the certain concept is approved by the state or the public authority, they will be considered to be acting illegally if they deviate from such policy or behavior. After all, the approval of the latter gave grounds for the emergence of reasonable expectations of individuals to adhere to such policies or behavior [8].

This example unequivocally shows the implementation of one of the ways of law development through interpretation and judicial law [6, p. 124]. Therefore, we must agree with the opinion of S.P. Pogrebniak, who notes that in some cases the interpretive and law enforcement functions of judicial practice are actually transformed into law-making. At the same time, the scientist notes that within the framework of the Romano-Germanic legal family, the lawmaking function of judicial practice, of course, is not the main one, but is performed as the additional one, supposedly complements the law enforcement or interpretation activities of the courts, compensates for the shortcomings of formal legal sources [9, p. 96-97].

As already mentioned, the problem of supplementing the law becomes especially relevant in bridging gaps in the law. In this regard, the question arises about the need to disclose the peculiarities of the interpretation of the rules applied by analogy.

The legal literature contains the point of view according to which, applying the law by analogy, the court or other law enforcement body should interpret it in the same way as in the usual application of this norm, since it is unacceptable to adapt the legal norm to similar relations by means of its different interpretation, transfer of the norm, which is applied in the sphere of other legal relations. Therefore, the meaning of the legal norm in its application by analogy cannot be distorted. At the same time, it should be borne in mind that each norm has its own sectoral (sub-sectoral) and institutional affiliation and is interpreted in conjunction with other norms contained in this area or institution. When applying the analogy, the rule of law is borrowed and allegedly transformed by the law enforcement body in the legal institution in which there is the gap. It follows that in the particular situation, such rule should be interpreted not as part of the institution from which it is borrowed, but as part of the institution, the gap in which it is designed to overcome [3, p. 107-108]. This is due to the fact that the norm, which is applied by analogy, is subject to double influence. On the one hand, it as a whole retains its original meaning, on the other - such a rule is partially adapted to the peculiarities of the institution, the gap in which, through it, is overcome. In addition, it should be remembered that when applying the rule by analogy, its general meaning is of paramount importance, which must remain unchanged. Some influence is also exerted by the specifics of the legal institution in which the borrowed norm is intended to be overcome. Thus, the rule applied by analogy in the certain sense is subject to adaptation by the enforcement authority.

Equally important is the issue of official interpretation, which plays the extremely important and sometimes decisive role in law. This is due to the fact that cases of authentic interpretation are the rather rare phenomenon, so it is logical that 
the so-called official explanations provided by higher judicial bodies become especially important. These powers are based on the provisions of the Law of Ukraine "On the Judiciary and the Status of Judges" of June 02, 2016 No.1402-VIII [10] (hereinafter referred to as the Law), according to which in order to ensure uniform application of law in resolving certain categories of cases, the Plenum of the Supreme Court practice of application of substantive and procedural laws, systematizes and ensures the promulgation of legal positions of the Supreme Court with reference to court decisions in which they were formulated (paragraph $10^{1}$ part 2 of Article 46 of Law No. 1402-VIII). Clause $10^{2}$ of the second part of the same article of the said Law determines that, based on the analysis of judicial statistics and generalization of judicial practice, the Plenum of the Supreme Court provides advisory clarifications on the application of law in deciding court cases. Providing these clarifications is primarily the need to ensure the common understanding and application of the law, through which stability is achieved in the development of legal relations.

The official interpretation of normative legal acts also plays the significant role in the case of formal gaps, when the more modern legal design is provided through the interpretation of legal norms. Such activities, as a rule, are associated with the interpretation of the relevant rules of law, giving them the broader or narrower meaning depending on the degree of change in the nature of relations governed by them [3, p. 111].

In objective reality, any interpretative act has the auxiliary character in relation to the existing normative legal act - the subject of interpretation, which finds its manifestation in the application of its relevant rules [11, p. 56]. As a result of interpretation, the so-called casual norms are formed (they are also called secondary), which are used to resolve the specific legal dispute, the specific case [12, p. 72-74]. The element of judicial lawmaking is especially noticeable in resolving so-called complex cases that cannot be resolved by simple rule-making and are considered in the presence of such shortcomings of the legal system as insufficient clarity of legal requirements, ambiguity of their understanding, gaps in legal regulation. When solving this category of cases, the judge uses an expanded law-making interpretation of the rule of law, applies the analogy of law and legislation, exercises judicial discretion, that is, selects one of several lawful decisions [7, p. 547].

Given the close interaction of the law-making function of the judiciary with law enforcement and interpretation, some lawyers express the opinion on the identity of judicial lawmaking and interpretation [13, p. 41; 14, p. 174]. At the heart of the problem of identifying these two concepts are two groups of reasons. The first of them is related to the peculiarities of judicial activity in legal systems of the Anglo-American type, where, in contrast to the Romano-Germanic law, there is no clear distinction between law-making and law-interpreting activities of the judiciary [15, p. 66, 147]. Other reasons for mixing these two categories are factors that necessitate the legislative function of the judiciary. This circumstance is, first of all, the uncertainty of the content of normative prescriptions with which the court operates in the process of administering justice [16, p. 4]. Therefore, in order to avoid the identification of the concepts of "judicial lawmaking" and "interpretive activity", as well as in order 
to formulate the general structure of "judicial lawmaking" in the legal literature, the only condition for the latter is to establish gaps in legal regulation.

Conclusions. Thus, based on the above considerations, we can conclude that the interpretation of the law is the necessary element of the mechanism of legal regulation. Its significance lies primarily in ensuring the full and accurate disclosure of the functions of legal acts as sources and forms of existence of legal norms, other substantive elements of the existing legal system, which makes this activity especially noticeable in the event of gaps in law. With the help of the interpretation procedure, one of the ways of completion (development) of law is realized, according to the concept of which the court is authorized to search for law outside the literal content of the law. This is what allows law enforcement agencies to ensure that legal cases are resolved in strict accordance with the constitutional principles of legal certainty, legality and the rule of law.

\section{References}

1. General theory of law : textbook / O.V. Petryshyn et al ; under reduction of O.V. Petryshyn. Kharkiv : Pravo, 2020. 568 p.

2. Bonner A.T. Sources of Soviet civil procedural law : textbook. M. : Legal Literature, 1977. 69 p.

3. Tumanov D.A. Gaps in civil procedural law : dis. ... PhD in Law : 12.00.15. M., 2007. 184 p.

4. Averin A.V. Law enforcement activity of the court and the formation of scientific and legal consciousness of judges: problems of theory and practice / Under reduction of M.I. Baitin. Saratov : SSU, 2003. $308 \mathrm{p}$.

5. Alekseev S.S. General theory of law : textbook, 2nd ed., Reworked and added. M. : TK Velbi, Prospekt, 2008. $576 \mathrm{p}$.

6. Pogrebniak S.P. The role of fundamental principles in the application of law. Problems of the philosophy of law, 2008 - 2009. VI - VII vol. Kyiv - Chernivtsi : Ruta, 2009. P. 124-134.

7. Shevchuk S.V. Judicial lawmaking : world experience and prospects in Ukraine. K. : Abstract, 2007. $640 \mathrm{p}$.

8. Court of Justice of the European Communities (CJEC) : Judgment of 4 December 1974, Yvonne van Duyn v Home Office, Case 41/74. Reports of Cases before the Court, 1974. P. 1337.

9. Pogrebniak S. The influence of judicial practice on legal acts in the Romano-Germanic legal family. Newsletter of Academy of Legal Sciences of Ukraine. 2003. №. 4 (35). P. 92-99.

10. On the Judiciary and the Status of Judges : Law of Ukraine of June 2, 2016 No. 1402-VIII. Information of the Verkhovna Rada. 2016. №. 31. P. 545. URL: https://zakon.rada.gov.ua/laws/ show/1402-19 (date of application: 10.09.2020).

11. Shapoval V. Official interpretation as the function of the Constitutional Court of Ukraine (problems of theory). Newsletter of Const. Court of Ukraine. 1999. №. 3. P. 52-57.

12. David R., Geoffre-Spinozi K. The main legal systems of our time: trans. from French M. : International Relations, $1996.400 \mathrm{p}$.

13. Vereshchagin A.N. Judicial lawmaking in Russia. Comparative legal aspects. M. : International Relations, 2004. $344 \mathrm{p}$.

14. Cherednichenko S. P. Judicial law-making: comparative legal research : dic. ... PhD in Law : 12.00.01. M., 2005. $203 \mathrm{p}$.

15. Lutz L.A. Modern legal systems of the world: textbook L. : Small publishing house of Legal Department LNU, 2003. $247 \mathrm{p}$.

16. Stetsyk N.V. Judicial lawmaking: general theoretical characteristics. Magazine of Academy of Advocacy of Ukraine. 2010. №. 8 (3). P. 1-6. 


\section{Summary}

Matat Yu. I. The role of interpretation of the law in the mechanism of bridging gaps in the law. -
Article.
The article is devoted to the study of the legal nature of the interpretation of law, its features, as well as the role in overcoming gaps in the law. Attention is focused and substantiated that the interpretation of legal norms, being a necessary element of the legal regulation mechanism, plays the important role in the process of overcoming gaps in law. So, by means of various methods of interpretation, in particular, formal gaps are overcome, which, in turn, may arise as a result of an unsuccessful presentation of legal norms by the legislator.

It is determined that when applying the rule of law by analogy, such a rule in the particular situation should be interpreted not as part of the institution from which it is borrowed, but as part of the institution, the gap in which it is designed to overcome. This is due to the fact that the rule applied by analogy is subject to double influence: on the one hand, it generally retains its original meaning, on the other - partially adapts to the characteristics of the institution in which the gap is overcome through it.

The role of official interpretation in the process of application of the law in the conditions of gaps in the legislation is clarified, the role of recommendatory explanations provided by higher courts on the issues of application of the legislation is investigated. In Ukraine, these powers, in accordance with the Law of Ukraine "On the Judicial System and the Status of Judges" dated June 02, 2016, are assigned to the Plenum of the Supreme Court, in order to ensure the same application of the rules of law in solving certain categories of cases, generalizes the practice of applying substantive and procedural laws, systematizes and ensures the promulgation legal positions of the Supreme Court, as well as based on the results of the analysis of judicial statistics and generalization of judicial practice, it provides explanations of the recommendatory nature on the application of legislation in solving court cases.

It is concluded that the importance of the interpretation of law is primarily to ensure full and accurate disclosure of the functions of legal acts as a source and form of existence of legal norms, other substantive elements of the legal system. The interpretation concretizes the law, which allows law enforcement agencies to ensure the resolution of legal cases in strict accordance with the constitutional principles of legal certainty, legality and the rule of law.

Key words: interpretation of law, gaps in law, law enforcement, completion (development) of law, judicial lawmaking.

\section{Анотація}

Матат Ю. І. Роль тлумачення права в механізмі подолання прогалин у законодавстві. - Стаття.

Стаття присвячена дослідженню юридичної природи тлумачення права, його особливостей, а також ролі в процесі подолання прогалин у законодавстві. Акцентується увага та обгрунтовується, що тлумачення норм права, будучи необхідним елементом механізму правового регулювання, відіграє важливу роль у процесі подолання прогалин у законодавстві. Так, за посередництвом різних способів тлумачення долаються, зокрема, формальні прогалини, які у свою чергу можуть виникати внаслідок невдалого викладення законодавцем правових норм.

Визначено, що в разі застосування норми права за аналогією така норма в конкретній ситуації має тлумачитися не як частина інституту, з якого ії запозичено, а як складник інституту, прогалину в якому вона покликана подолати. Указане пов'язано з тим, що норма, застосовувана за аналогією, піддається подвійному впливу: з одного боку, вона в цілому зберігає первинний смисл, з другого - частково пристосовується до особливостей того інституту, прогалина в якому долається за її посередництвом.

3'ясовано роль офіційного тлумачення в процесі застосування права в умовах прогалин у законодавстві, досліджено роль рекомендаційних роз'яснень, що надаються вищими судами, з питань застосування законодавства. В Україні зазначені повноваження згідно із Законом України «Про судоустрій і статус суддів» від 02.06.2016 р. покладено на Пленум Верховного Суду, який з метою забезпечення однакового застосування норм права під час вирішення окремих категорій справ узагальнює практику застосування матеріального і процесуального законів, систематизує та забезпечує оприлюднення правових позицій Верховного Суду, а також за результатами аналізу судової статистики та узагальнення судової практики надає роз'яснення рекомендаційного характеру з питань застосування законодавства у вирішенні судових справ.

Зроблено висновок, що значення тлумачення права полягає насамперед у забезпеченні повного й точного розкриття функцій правових актів як джерела й форми існування юридичних норм, інших змістовних елементів правової системи. За допомогою тлумачення здійснюється конкретизація права, яка дає змогу правозастосовним органам забезпечити вирішення юридичних справ у суворій відповідності конституційним принципам правової визначеності, законності й верховенства права.

Ключові слова: тлумачення права, прогалини в законодавстві, правозастосування, добудова (розвиток) права, судова правотворчість. 